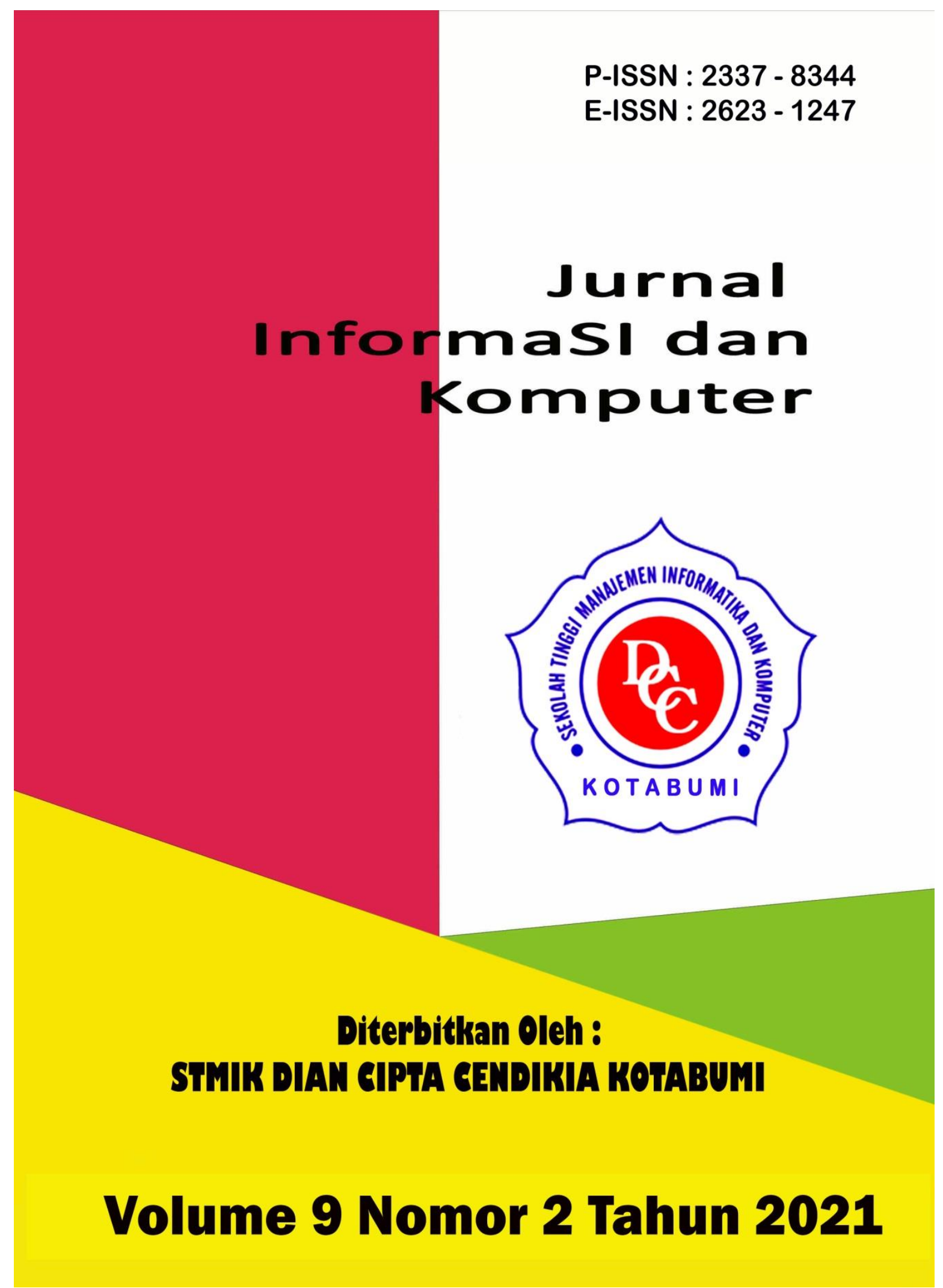




\section{Penerbit}

\section{Lembaga Penelitian STMIK Dian Cipta Cendikia Kotabumi}

Hak atas naskahh/tulisan tetap berada pada penulis, isi diluar tangung jawab penerbit dan Dewan Penyunting 


\section{PENGANTAR REDAKSI}

Puji syukur dipanjatkan kehadirat Tuhan Yang Maha Esa, atas karunia dan limpahan rahmatNYA jualah Jurnal Informasi dan komputer (JIK) STMIK Dian Cipta Cendikia Kotabumi ini dapat terwujud.Jurnal Informasi dan Komputer (JIK) yang terbit dua (2) kali dalam setahun ini merupakan suatu wadah untuk penyebar luasan hasil-hasil penelitian, studi pustaka, karya ilmiah yang berkaitan dengan Informasi dan Komputer khususnya bagi dosen-dosen STMIK Dian Cipta Cendikia Kotabumi serta umumnya para cendikiawan, praktisi, peneliti ilmu Informatika dan Komputer.

Harapan, dengan diterbitkannya Jurnal Informasi dan Komputer (JIK) ini sebagai salah satu bentuk sumbangan pemikiran dalam pengembangan ilmu informatika dan komputer yang berkaitan dengan kajian-kajian di bidang tekhnologi Informatik, Komunikasi Data dan Jaringan Komputer, perancangan dan Rekayasa Perangkat Lunak, serta ilmu-ilmu yang terkait dengan bidang Informasi dan Komputer lainnya.

Berkenaan dengan harapan tersebut, kepada para peneliti, dosen dan praktisi yang memiliki hasil-hasil penelitian, kajian pustaka, karya ilmiah dalam bidang tersebut diatas, dengan bangga redaksi Jurnal Informasi dan Komputer (JIK) menerima naskah ringkasan untuk dimuat pada jurnal Informasi dan Komputer (JIK) STMIK Dian Cipta Cendikia Kotabumi dengan berpedoman pada penulisan naskah jurnal sebagaimana dilampirkan pada halaman belakang (Bagian kulit dalam) buku jurnal ini.

Mutu dari suatu jurnal ilmiah tidak hanya ditentukan oleh para pengelolanya saja, tetapi para penulis dan pembaca jualah yang mempunyai peranan besar dalam meningkatkan mutu jurnal Informatika dan Komputer ini. Merujuk pada realita ini kamu sangat mengharapkan peran aktif dari peneliti untuk bersama-sama menjaga dan memelihara keberlangsungan dari jurnal Informasi dan Komputer STMIK Dian Cipta Cendikia Kotabumi ini. Yang juga tidak kalah pentingnya dari partisipasi tersebut diatas, adalah saran dan kritik yang membangun dari pembaca yang budiman agar kiranya dapat disampaikan langsung kepada redaksi JIK. Saran dan kritik yang membangun akan dijadikan masukan dan pertimbangan yang sangat berarti guna peningkatan mutu dan kualitas Jurnal Informasi dan Komputer STMIK Dian Cipta Cendikia Kotabumi.

Tak lupa diucapkan terima kasih yang tak terhingga atas perhatian dan kerjasama dari semua pihak yang tak dapat disebutkan satu persatu hingga dapat diterbitkan nya Jurnal Informasi dan Komputer (JIK) STMIK Dian Cipta Cendikia Kotabumi. Semoga apa yang telah diperbuat untuk kebaikan akan menjadi amal ibadah, amin.

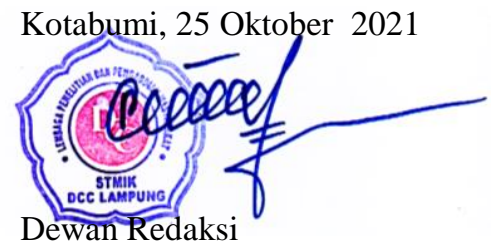




\section{JURNAL INFORMASI DAN KOMPUTER}

Volume 9 Nomor 2 Oktober 2021

Jurnal Informasi dan Komputer merupakan Sarana informasi ilmu pengetahuan, Tekhnologi dan Komunikasi yang berupa hasil penelitian, tulisan ilmiah, Ataupun studi pustaka. Jurnal ini terbit dua kali setahun pada bulan April dan Oktober. Berisi hasil penelitian ilmiah di bidang informatika yang bertujuan untuk menghubungkan adanya kesenjangan antar kemajuan teknologi dan hasil penelitian. Jurnal ini di terbitkan pertama kali pada tahun 2013.

Penanggung Jawab:

Ketua STMIK Dian Cipta Cendikia Kotabumi

\section{Pembina:}

Ketua STMIK Dian Cipta Cendikia Kotabumi Ketua Lembaga Penelitian STMIK Dian Cipta Cendikia Kotabumi

\section{Pimpinan Redaksi}

Dwi Marisa Efendi,.S.Kom.,M.Ti

\section{Redaksi pelaksana}

Rustam,.S.Kom,.M.Ti (STMIK Dian Cipta Cendikia Kotabumi)

Nurmayanti M.Kom (STMIK Dian Cipta Cendikia Kotabumi)

Sukatmi,.S.Kom., M.Kom (AMIK DCC Bandar Lampung)

Sampurna Dadi Riskiono,M.Kom (Universitas Teknokrat Indonesia)

Ifo Wahyu Pratama,S.Kom.,M.Ti(AMIK MASTER Lampung)

\section{Mitra Bestari}

Dr. RZ. ABDUL AZIZ, ST., MT (Institut Informatika dan Bisnis Darmajaya)

Dr. Dadang Sudrajat, S.Si, M.Kom (STMIK IKMI Cirebon)

Dr. Septafiansyah Dwi Putra, S.T., M.T (Politeknik Negeri Lampung)

Dr. Evi Grativiani, S.E., M.S.I (Universitas Sebelas Maret)

Rohmat Indra Borman ( Universitas Teknokrat Indonesia )

Ferry Wongso, S.KOm., M.Kom ( STMIK Darma Pala Riau)

Ferly Ardhy, S.Kom., M.Ti ( Universitas Aisyah Pringsewu )

Firmansyah, S.E., M.Si (STMIK Darma Pala Riau)
Amarudin (Universitas Teknokrat Indonesia)

Didi Susianto, S.T., M.Kom (AMIK Dian Cipta Cendika Bandar Lampung)

Alhibarsyah, St., M.Kom (STMIK Tunas

Bangsa Bandar Lampung)

Kemal Farouq Mauladi, S.Kom .M.Kom (Universitas Islam Lamongan)

Rima Mawarni, M.Kom ( STMIK Dian Cipta Cendikia Kotabumi)

Wira Jaya Hartono, S.Pd., M.Pd ( STMIK Darma Pala Riau)

Penerbit : STMIK Dian Cipta Cendikia Kotabumi Bekerja Sama Dengan LPPM STMIK Dian Cipta Cendikia Kotabumi.

\section{Alamat Redaksi/Penerbit:}

Jl. Negara No. 3 Candimas Kotabumi Lampung Utara

No Telpon/Fax 072423003

Email : 1ppm-stmik@dcc.ac.id 


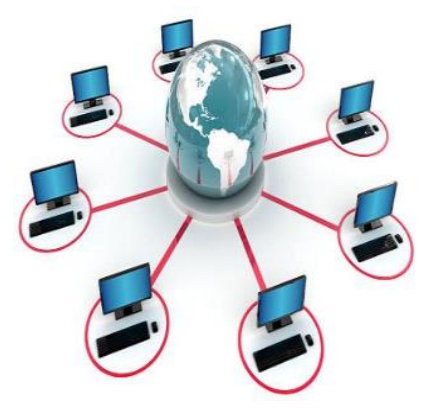

\section{JURNAL INFORMASI DAN KOMPUTER VOL. 9 NO. 2 THN. 2021}

\section{DAFTAR ISI}

Halaman

Sistem Informasi Akuntansi Persedian Barang Berbasis Web Pada Lembaga

Permasyarakatan Kelas II A Banceuy Bandung : "Kelompok Tani Desa Banjar Kertarahayu” Teuku Rian Hardiyansyah, Fatia Salsa Azzahra (Politeknik Piksi Ganesha Bandung ${ }^{1,2}$ ).

Penerapan Finite State Automata Pada Vending Machine Penjual Obat Non Resep

Dokter Dan Keperluan Medis

Eko Supriyanto $^{1}$, Angga Ardiansyah ${ }^{2}$, Frieyadie $^{3}$, Sri Rahayu ${ }^{4}$, Windu Gata ${ }^{5}$

(Universitas Nusa Mandiri ${ }^{12}$ )

Sistem Pendukung Keputusan Untuk Menentukan Kelayakan Pengajuan Sertifikasi Guru Dengan Metode Simple Additive Weighting (Studi Kasus : Ma Al Muhajirin Janti Jogoroto Jombang)

Budiman, umam baharudin, winarti

(Universitas Darul 'Ulum Jombang)

Perancangan Infrastruktur Domain Name Server Lokal Menggunakan Ubuntu Server 16.04

Pada PT. Xyz

Zaenal Mutaqin Subekti, Hendra Setiawan, Satria, Widia Murni Wijaya,

Aliy Hafiz, Warsudi

(STMIK Bani Saleh, Universitas Negeri Yogyakarta, AMIK Dian Cipta Cendikia,

STMIK MIC CIkarang)

Perancangan Sistem Informasi Idea Proposal (Ip) Berbasis Web Pada Pt. Paxel Algorita Unggul

Julian Murhan Sahputra, Indah Purnamasari

(Universitas Nusa Mandiri ${ }^{12}$ )

Sistem Pendukung Keputusan Untuk Menentukan Ekstrakurikuler Atletik

Berdasarkan Bakat Siswa Menggunakan Metode Profile Matching

Agnes Basuki, Petrus Sokibi, Tiara Eka Putri

(Universitas Catur Insan Cendekia)

Penerapan Algoritma K-Means Untuk Pengelompokan Usia Calon Penerima Vaksin

Di Kab. Ngawi

Irna Yuniarfi, Saifulloh

(Universitas PGRI Madiun ${ }^{12}$ )

System Penilaian Seleksi Calon Karyawan Baru Menggunakan Metode Simple Additive Weighting (SAW) Di PT.TNA

Anik Sri Wahyuningsih, Yudhi Firmansyah

(Universitas Panca Sakti Bekasi ) 
Perancangan Sistem Informasi Pembayaran SPP Menggunakan Framework Laravel Ichwan Habib Moudi

(Universitas Panca Sakti Bekasi)

Implementasi Algoritma K-Means Dan Algoritma Apriori Optimasi Kinerja Ecu

(Study Kasus Mobil Avanza Dan Xenia)

Sigit Mintoro' Asep Afandi

(STMIK Dian Cipta Cendikia Kotabumi)

Sistem Pakar Penyakit Buah Kakao Untuk Peningkatan Hasil Panen Kakao Menggunakan

Metode Case Base Reasoning (CBR) Berbasis Web Mobile

Aliy hafiz, Verawati

(AMIK Dian Cipta Cendikia,Bandar Lampung)

Penerapan Metode Rapid Application Develomment (RAD) Dalam Pengembangan

Sistem Pemesanan Menu Berbasis Android

Aris Baihaqi, Tumini

(Fakultas Sains dan Teknologi ${ }^{1,2}$ )

Rancang Bangun Sistem Informasi Geografis Pariwisata Di Lampung Timur

Sukatmi, Rexa Alfa Rizi

(AMIK DCC Bandar Lampung ${ }^{12}$ )

Implementasi Psak No. 45 Pada Proses Penyusunan Laporan Keuangan Menggunakan

M.S. Excel Dan Aplikasi Accurate Accouting Pada STMIK Bani Saleh

Marhakim, Willy Adam

(STMIK Bani Saleh ${ }^{12}$ )

Sistem Prediksi Harga KOPI LAMBAR ( Lampung Barat) Dengan Metode

Backpropagation, dan Double Exponential ( Studi Kasus BUMDES )

Supriyanto, Dwi marisa Efendi,Rhomadhon

(STMIK Dian Cipta cendikia Kotabumi ${ }^{1-}$ )

Sistem Informasi Pemasaran Produk Umkm Berbasis Web Pada Kecamatan Bumi

Nabung Lampung Tengah

Yuli Syafitri, Agus Prasetyo, Reni Astika

(AMIK Dian Cipta Cendikia Bandar Lampung)

Rancang Bangun Aplikasi Pembelajaran Aksara Lampung Berbasis Android

Ferly Ardhy, Hendra Syahrobi

(Universitas Aisyah Pringewu ${ }^{1,}$ STMIK Dian Cipta Cendikia ${ }^{2}$ )

Sistem Pakar Diagnosa Penyakit Kulit Pada Balita Menggunakan Metode Naïve

Bayes Dan Forward Chaining Studi Kasus Puskesmas Cempaka Sungkai Selatan

Sidik Rahmatullah, Rima Mawarni

(STMIK Dian Cipta Cendikia Kotabumi ${ }^{12}$ )

Rekayasa Perangkat Lunak Perhitungan Harga Pokok Produksi Metode

Full Costing Pada Umkm Mitra Cake Di Bandar Lampung

Pitrawati, Arif Sanjaya

(AMIK Dian Cipta Cendikia, Bandar Lampung) 
Rancang Bangun Sistem Ujian Online Menggunakan Algoritma Cosine Similarity

Berbasis Web

Haryono, Zaenal Mutaqin Subekti, Widiyawati, Hidayatullah

(STMIK Bani Saleh ${ }^{1234}$ )

Model Aplikasi Helpdesk Ticketing System Berbasis Web Menggunakan Metode Rad

Indra Permana

Pattern Recognition Tulisan Tangan Huruf Hijaiyah Menggunakan Metode

Convolutional Neural Network (CNN)

Mufassiril Abror, Nopiyanto

(Universitas Panca Sakti Bekasi ${ }^{12}$ )

Aplikasi Sistem Informasi Keuangan Berbasis Android Di Perumahan Taman

Karang Bahagia

Melda Ayulestari

(Universitas Panca Sakti Bekasi)

Audit Pelayanan Sistem Rujukan Online Puskesmas Menggunakan Framework COBIT 5.0

Nurmayanti, Merri Parida, Ngajiyanto, Ina Anzalna

(STMIK Dian Cipta Cendikia Kotabumi ${ }^{1234}$ )

Perancangan Sistem Informasi Pengolahan Data Nilai Siswa Berbasis Web

Erin Ermawati, Anik Sri Wahyuningsih

(Fakultas Sain dan Teknologi, Universitas Panca Sakti Bekasi ${ }^{12}$ )

Pengembangan Sistem Pelaporan Data Hasil Inspeksi Barang Berbasis Web

Siska Putriani

(Universitas Pancasakti Bekasi)

Penerapan Extreme Programming Dalam Perancangan Aplikasi Web Food Market

Tumini, Hilman Septiana

(Fakultas Sains dan Teknologi Universitas Panca Sakti Bekasi ${ }^{1,2}$ )

Sistem Pencarian Barang Berbasis Website Menggunakan Php Dan Mysql

Studi Kasus PT. Surya Technology Industri Sulaeman

(Universitas Panca Sakti Bekasi)

Implementasi Metode Prototype Pada Sistem Peminjaman Alat Kerja Berbasis Web

Di PT SK Metalindo

Ali Mulyanto, Arjun Gunawan

(Univeritas Panca Sakti Bekasi)

Aplikasi Tata Cara Wudhu Menggunakan Teknologi Augmented Reality

Sebagai Media Pembelajaran Di TK Al Fatih

Ahmad Yakub , Idarul Fadli

(Universitas Panca Sakti Bekasi ${ }^{12}$ )

Sistem Pakar Diagnosa Penyakit Ayam Petelur Menggunakan Metode Certainty Factor

Berbasis Web Mochammad

Taufiq Hidayat, Ali Mulyanto

(Universitas Panca Sakti Bekasi ${ }^{12}$ ) 
Penerapan Metode Prototyping Dalam Perhitungan Hasil Produksi Menggunakan

Arduino Uno R3 Dan Php Di PT. Indonesia Epson Industry

Amandha Aulia, Ajar Rohmanu

(Universitas Panca Sakti Bekasi ${ }^{12}$ )

System Pendukung Keputusan Penentuan Guru Teladan Dengan Metode Profile Matching

Hasbulloh, Agmawarnida

(Universitas Panca Sakti Bekasi ${ }^{1,2}$ )

Implementasi Waterfall Method Pada Aplikasi Buku Induk Siswa Berbasis Web

Idam Holid, Yogie Krisnayadi

(Universitas Panca Sakti ${ }^{12}$ )

Pengembangan Text To Speech Media Pembelajaran Untuk Pengenalan

Anggota Tubuh Manusia Kelas V Sekolah Dasar

Juwanda Saputra, Ali Mulianto

(Teknik Infomratika Fakulutas Sains dan Teknologi ${ }^{12}$ )

Perancangan Sistem Peminjaman Barang Berupa Aset Tetap Berbasis Web

Pada Lembaga Permasyarakatan Kelas II A Banceuy Bandung

Guntur Salasa Priambodo, Perwito, Candra Mecca Sufyana

(Politeknik Piksi Ganesha Bandung ${ }^{1,2,3}$ )

Metode Pemilihan Karyawan Terbaik Sebagai Penentu Goodwill Perguruan Tinggi

Dengan Menggunakan Metode Topsis (Studi Kasus Perguruan Tinggi Di Lampung Utara)

Dwi Sartika, Pakarti Riswanto

(STMIK Dian Cipta Cendikia Kotabumi)

Sistem Pendukung Keputusan Pemilihan Merek Smartphone Menggunakan

Metode Analytical Hierarchy Process (AHP)

Ade Kiki Fatmawati, Muhammad Sultan Raflie, Norma Yunita

(Universitas Nusa Mandiri ${ }^{123}$ )

Pattern Recognition Aksara Lampung Menggunakan Algoritma Neural Network

Metode Analytical Hierarchy Process (AHP)

Nopiyanto, Rahmadi

(Universitas Panca Sakti Bekasi) 


\title{
IMPLEMENTASI ALGORITMA K-MEANS DAN ALGORITMA APRIORI OPTIMASI KINERJA ECU (STUDY KASUS MOBIL AVANZA DAN XENIA)
}

\author{
Sigti Mintoro ${ }^{1,}$ Asep Afandi ${ }^{2}$ \\ STMIK Dian Cipta Cendikia Kotabumi \\ JL. Negara Candimas Kotabumi Lampung Utara \\ Email : SigitMIntoro76@gmail.com, Asepafandi189@Gmail.Com
}

\begin{abstract}
ABSTRAK
Saat ini sistem kendaran sudah dikontrol menggunakan elektronik ECU (Engine Control Unit) .Kerusakan ECU akan mempengaruhi kinerja mesin, maka dibutuhkan sistem yang dapat menangani permasalahan dalam medeteksi secara akurat cepat dalam mengambil keputusan. Dalam clustering data, terdapat beberapa algoritma yang dapat digunakan, seperti, Algoritma K-Means dan Algoritma A Priori adalah algoritma dengan tingkat akurasi yang tinggi dan terbaik di antara ketiga algoritma ini dengan cara melakukan perbandingan menggunakan Rapidminer. Perbandingan algoritma bertujuan untuk mendapatkan hasil dan prediksi dari penelitian yang telah dilakukan. Pengembangan Sistem Analisis dengan K-Mains dan Data Clustering ini menjadi solusi untuk membantu menganalisis data-data dalam proses menganalisa optimasi kinerja ECU terhadap kinerja mesin kendaraan meliputi pengambilan data, mengolah data, medeteksi kelemahan dalam perubahan data digital agar dengan cepat dapat mengoptimalkan kinerja ECU dalam pengelompokan data menggunakan K-means clustering. Dari Hasil penelitian Clustering K-Means didapat C1(781-784), C2(896-927), C3(1223-1321), C4(1460-1587), dan C5(1689-2716) Engine RPM dan A-Priori Suport AUB rata- rata 20\%, Suport A rata-rata 80\% dan nilai Confidence Rata-Rata $80 \%$. Berdasarkan Pada remapping variasi 3 derajat pengapian maju menghasilkan Daya mesin dan torsi mesi stabil pada putaran rendah $1000 \mathrm{rpm}$ ke putaran tinggi $2176 \mathrm{rpm}$ dengan remapping sesuai dengan kondisi mesin pada saat pengujian.
\end{abstract}

Kata Kunci : Algoritma K-Means, Algoritma A Priori, ECU, Remapping

\begin{abstract}
Currently the vehicle system has been controlled using an electronic ECU (Engine Control Unit). ECU damage will affect engine performance, so a system that can handle problems accurately detects quickly in making decisions is needed. In data clustering, there are several algorithms that can be used, such the K-Means Algorithm and the A Priori Algorithm, which is an algorithm with a high level of accuracy and the best among these three algorithms by doing a comparison using Rapidminer. Comparison of algorithms aims to obtain results and predictions from research that has been done. The development of the Analysis System with K-Mains and Data Clustering is a solution to help analyze data in the process of analyzing the optimization of ECU performance on vehicle engine performance including data collection, processing data, detecting weaknesses in digital data changes so that they can quickly optimize ECU performance in data grouping using K-means clustering. From the results of the K-Means Clustering study, it was found that C1(781-784), C2(896-927), C3(1223-1321), C4(1460-1587), and C5(1689-2716) Engine and A-Priori AUB support an average of 20\%, Support A an average of $80 \%$ and an average Confidence value of $80 \%$. Based on the remapping variation of 3 degrees of forward ignition produces engine power and stable engine torque at low speed of $781 \mathrm{rpm}$ to high speed $2176 \mathrm{rpm}$ with remapping engine conditions at the time of testing.
\end{abstract}

Keywords: K-Means Algorithm, the A Priori Algorithm, ECU, Remapping

81 |S T M I K D i a n C i p t a C e n d i k i a Ko t a bu m i 


\section{PENDAhuluan}

Performa mesin mobil modern saat ini sebagian besar sudah menggunakan kontrol utamanya ke perangkat ECU seperti remapping, piggyback, rechipping. Metode piggyback adalah modul aftermarket berguna memanipulasi data yang masuk ke dalam ECU. ECU adalah otak dari kendaraan. Benda ini menginput data dari berbagai sensor, memprosesnya, lantas dikirimkan kembali ke komponen terkait supaya direspons. Mirip otak manusia, yang mendeteksi segala hal, lalu mengirimkan sinyal ke bagian tubuh untuk bereaksi sesuai yang diinginkan. Sementara mesin, bisa dianalogikan sebagai jantung dari sebuah kendaraan[1]. Sedangkan remapping ECU memprogram ulang data atau map yang ada pada ECU standar agar performa bisa naik. Pengolahan data dari berbagai sensorsensor yaitu throttle position sensor (TPS), Intake Air Temperatur sensor (IATS), Manifold Air Pressure (MAP), Crank Position Sensor, dan Coolant temperatur sensor. Informasi dari sensor-sensor tersebut akan diproses oleh mikrokontroler untuk memerintah actuator yaitu injector, coil, fuel pump dan fan.

Dalam melakukan remapping ECU perlu tindakan khusus, baik secara mekanis maupun secara komputasi. Pengaturan-pengaturan ulang dan perbandingan nilai alogaritma dalam ECU disebut engine remapping ini sangat penting dilakukan sehingga dapat teratasi dengan cepat dan akurat agar tidak terjadi kerusakan pada sensor dan actuator sehingga performa mesin mengalami dapat dikontrol.

Kerusakan ECU akan mempengaruhi kinerja mesin, maka dibutuhkan sistem yang dapat menangani permasalahan dalam medeteksi secara akurat cepat dalam mengambil keputusan. Dalam Clustering data, terdapat beberapa algoritma Clustering yang dapat digunakan, seperti Algoritma K-Means dan Algoritma A Priori adalah algoritma dengan tingkat akurasi yang tinggi.

Berdasarkan uraian diatas, maka penulis ingin menganalisa dan mengimplementasikan menggunakan metode algoritma K- Medoids , Algoritma K-Means dan Algoritma A Priori untuk memperoleh kesimpulan-kesimpulan yang akurat, dengan melalui proses-proses perubahan data alograitma logic dari ECU .

\section{METODE PENELITIAN}

\subsection{ECU ( Electronic Control Unit )}

Engine Control Unit merupakan sebuah komputer yang mengendalikan segala hal dalam mesin, mulai dari penguncian kendaraan ketika mesin mati sampai dengan kontrol waktu yang tepat untuk api pertama saat mesin dinyalakan. ECU adalah otak dari kendaraan. Benda ini menginput data dari berbagai sensor, memrosesnya, lantas dikirimkan kembali ke komponen terkait supaya direspons. Mirip otak manusia, yang mendeteksi segala hal, lalu mengirimkan sinyal ke bagian tubuh untuk bereaksi sesuai yang diinginkan. Sementara mesin, bisa dianalogikan sebagai jantung dari sebuah kendaraan[1].

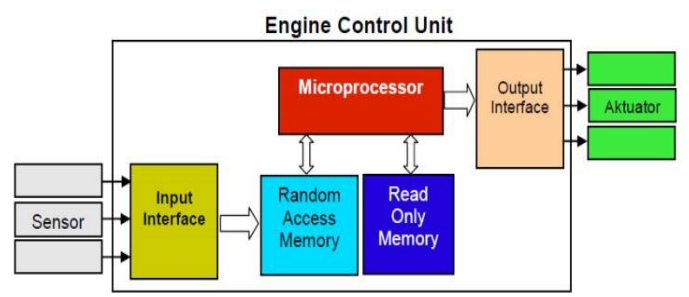

Gambar 1. Pengendali ECU diagram

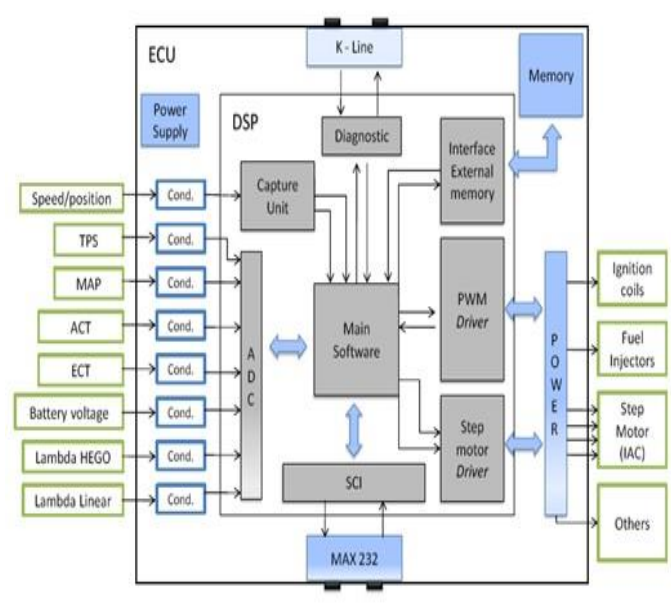

Gambar. 2. Diagram Sensor yang dikontrol ECU 
Engine Management System terdiri dari input sensor, Engine Control Unit (ECU) dan output actuator.Electronic Control Unit merupakan komponen sistem bahan bakar yang akan menerima sinyal listrik dari sensor kemudian dijadikan garis perintah kepada sensor dan actuator terlihat pada gambar 2. ECU mendapat suplay tegangan listrik dari bateray dan dialirkan ke sensor dan actuator yang disesuaikan dengan kebutuhan sensor ataupun actuator.

\subsection{K-Means}

K-means ditemukan oleh beberapa orang yaitu Lloyd (1957, 1982), Forgey (1965), Friedman and Rubin (1967), and McQueen (1967) . Ide dari clustering pertama kali ditemukan oleh Lloyd pada tahun 1957, namun hal tersebut baru dipublikasi pada tahun 1982. Pada tahun 1965, Forgey juga mempublikasi teknik yang sama sehingga terkadang dikenal sebagai LloydForgy pada beberapa sumber [3].

Proses pengelompokkan data ke dalam suatu cluster dapat dilakukan dengan cara menghitung jarak terdekat dari suatu data ke sebuah titik centroid. Perhitungan jarak Minkowski dapat digunakan untuk menghitung jarak antar 2 buah data. Rumus untuk menghitung jarak tersebut adalah:

$$
d\left(x_{i}, x_{j}\right)=\left(\left|x_{i 1}-x_{j 1}\right|^{9}+\left|x_{i 2}-x_{j 2}\right|^{9}+\ldots+\left|x_{i p}-x_{j p}\right|^{g}\right)^{1 / g}
$$

Di mana:

$\mathrm{g}=1$, untuk menghitung jarak Manhattan

$\mathrm{g}=2$, untuk menghitung jarak Euclidean

$\mathrm{g}=\infty$, untuk menghitung jarak Chebychev

$\mathrm{x}_{\mathrm{i}}, \mathrm{x}_{\mathrm{j}}$ adalah dua buah data yang akan dihitung jaraknya

$\mathrm{p}=$ dimensi dari sebuah data

Pembaharuan suatu titik centroid dapat dilakukan dengan rumus berikut ${ }^{[4]}$ :

$$
\mu_{k}=\frac{1}{N_{k}} \sum_{q=1}^{N_{k}} x_{q}
$$

Di mana:

$\mu_{\mathrm{k}}=$ titik centroid dari cluster ke- $\mathrm{K}$

$\mathrm{N}_{\mathrm{k}}$ = banyaknya data pada cluster ke-K

$\mathrm{x}_{\mathrm{q}}=$ data ke-q pada cluster ke-K

\subsection{Algoritma A Priori}

Algoritma apriori adalah jenis aturan asosiasi pada data mining. Algoritma ini ditujukan untuk mencari kombinasi itemset yang mempunyai suatu nilai keseringan tertentu sesuai kriteria atau filter yang diinginkan. Algoritma ini diajukan oleh R. Agrawal dan R. Srikant tahun 1994[3]. Hasil dari algoritma ini dapat digunakan untuk membantu dalam pengambilan keputusan pihak manajemen. Algoritma apriori melakukan pendekatan iteratif yang dikenal dengan pencarian level-wise, dimana k-itemset digunakan untuk mengeksplorasi atau menemukan $(k+1)$ - itemset. Oleh karena itu, algoritma apriori dibagi menjadi beberapa tahap yang disebut iterasi. Tiap iterasi menghasilkan pola frekuensi tinggi dengan panjang yang sama dimulai dari iterasi pertama yang menghasilkan pola frekuensi tinggi dengan panjang satu.

\section{HASIL DAN PEMBAHASAN}

\subsection{K- Means}

Tabel 2 Jumlah Cluster

\begin{tabular}{|c|c|c|c|}
\hline & & & $\begin{array}{c}\text { Engine } \\
\text { RPM }\end{array}$ \\
\hline Cluster & $\begin{array}{l}\text { Pusat } \\
\text { Cluster }\end{array}$ & Time & \\
\hline C1 & 2 & 35,9 & 790 \\
\hline C3 & 6 & 37,2 & 897 \\
\hline C4 & 11 & 35,1 & 1223 \\
\hline C5 & 21 & 19,9 & 1666 \\
\hline
\end{tabular}


Table 3. Perhitungan K Means

\begin{tabular}{|c|c|c|c|c|c|c|c|c|}
\hline \multirow{2}{*}{$\begin{array}{l}0 \\
0 \\
0 \\
\dot{x}\end{array}$} & \multirow{2}{*}{$\begin{array}{l}\mathrm{T} \\
\mathrm{i} \\
\mathrm{m} \\
\mathrm{e}\end{array}$} & $\begin{array}{l}\mathrm{E} \\
\mathrm{n} \\
\mathrm{g} \\
\mathrm{i} \\
\mathrm{n}\end{array}$ & \multicolumn{5}{|c|}{ CLUSTERING } & \multirow[b]{2}{*}{$\begin{array}{c}\mathrm{CL} \\
\mathrm{US} \\
\mathrm{TE} \\
\mathrm{R}\end{array}$} \\
\hline & & $\begin{array}{l}\mathrm{e} \\
\mathrm{R} \\
\mathrm{P} \\
\mathrm{M}\end{array}$ & C1 & $\mathrm{C} 2$ & C3 & C4 & C5 & \\
\hline 1 & $\begin{array}{l}3 \\
5 \\
7\end{array}$ & $\begin{array}{l}7 \\
8 \\
1\end{array}$ & $\begin{array}{r}81, \\
2\end{array}$ & $\begin{array}{r}13 \\
45 \\
7 \\
5\end{array}$ & $\begin{array}{r}19 \\
53 \\
64 \\
6\end{array}$ & $\begin{array}{r}46 \\
10 \\
42 \\
, 7\end{array}$ & $\begin{array}{r}78 \\
32 \\
40 \\
8\end{array}$ & 1 \\
\hline 2 & $\begin{array}{l}3 \\
5 \\
9\end{array}$ & $\begin{array}{l}7 \\
9 \\
0\end{array}$ & 0 & $\begin{array}{c}11 \\
45 \\
0 \\
3\end{array}$ & $\begin{array}{r}18 \\
74 \\
89 \\
8\end{array}$ & $\begin{array}{r}44 \\
89 \\
01 \\
, 5\end{array}$ & $\begin{array}{l}76 \\
73 \\
92\end{array}$ & 1 \\
\hline 3 & $\begin{array}{l}3 \\
6 \\
2\end{array}$ & $\begin{array}{l}7 \\
8 \\
8\end{array}$ & 4,3 & $\begin{array}{r}11 \\
88 \\
2\end{array}$ & $\begin{array}{r}18 \\
92 \\
26 \\
1\end{array}$ & $\begin{array}{r}45 \\
15 \\
85 \\
, 2\end{array}$ & $\begin{array}{r}77 \\
09 \\
00 \\
3\end{array}$ & 1 \\
\hline 4 & $\begin{array}{l}3 \\
6 \\
4 \\
4\end{array}$ & $\begin{array}{l}7 \\
8 \\
4\end{array}$ & $\begin{array}{r}36, \\
5\end{array}$ & $\begin{array}{r}12 \\
76 \\
9 \\
8\end{array}$ & $\begin{array}{r}19 \\
27 \\
22 \\
3\end{array}$ & $\begin{array}{l}45 \\
69 \\
77\end{array}$ & $\begin{array}{r}77 \\
79 \\
40 \\
5\end{array}$ & 1 \\
\hline 5 & $\begin{array}{l}3 \\
7 \\
8\end{array}$ & $\begin{array}{l}8 \\
9 \\
6\end{array}$ & $\begin{array}{r}11 \\
23 \\
7,9\end{array}$ & $\begin{array}{l}1, \\
6\end{array}$ & $\begin{array}{r}10 \\
69 \\
31 \\
7\end{array}$ & $\begin{array}{r}31 \\
80 \\
96 \\
4\end{array}$ & $\begin{array}{r}59 \\
29 \\
17 \\
, 9\end{array}$ & 2 \\
\hline 6 & $\begin{array}{l}3 \\
7 \\
2 \\
2\end{array}$ & $\begin{array}{l}8 \\
9 \\
7\end{array}$ & $\begin{array}{r}11 \\
45 \\
0,3\end{array}$ & 0 & $\begin{array}{l}10 \\
62 \\
78 \\
1\end{array}$ & $\begin{array}{r}31 \\
69 \\
69 \\
, 2\end{array}$ & $\begin{array}{r}59 \\
13 \\
78 \\
, 3\end{array}$ & 2 \\
\hline 7 & $\begin{array}{l}3 \\
8 \\
5\end{array}$ & $\begin{array}{l}8 \\
9 \\
7\end{array}$ & $\begin{array}{c}11 \\
45 \\
1,6\end{array}$ & $\begin{array}{l}1, \\
3\end{array}$ & $\begin{array}{r}10 \\
62 \\
79 \\
4\end{array}$ & $\begin{array}{r}31 \\
69 \\
70 \\
, 1\end{array}$ & $\begin{array}{r}59 \\
13 \\
79 \\
6\end{array}$ & 2 \\
\hline 8 & $\begin{array}{l}3 \\
9\end{array}$ & $\begin{array}{l}8 \\
9 \\
4\end{array}$ & $\begin{array}{r}10 \\
81 \\
9,1\end{array}$ & $\begin{array}{r}10 \\
, 8\end{array}$ & $\begin{array}{r}10 \\
82 \\
44 \\
9\end{array}$ & $\begin{array}{r}32 \\
03 \\
57 \\
6\end{array}$ & $\begin{array}{r}59 \\
60 \\
03 \\
1\end{array}$ & 2 \\
\hline 9 & $\begin{array}{l}3 \\
9\end{array}$ & $\begin{array}{l}9 \\
2 \\
2\end{array}$ & $\begin{array}{r}17 \\
42 \\
7,1\end{array}$ & $\begin{array}{c}62 \\
6 \\
8\end{array}$ & $\begin{array}{r}90 \\
60 \\
4 \\
9\end{array}$ & $\begin{array}{r}28 \\
94 \\
45 \\
, 6\end{array}$ & $\begin{array}{r}55 \\
35 \\
55 \\
1\end{array}$ & 2 \\
\hline 0 & $\begin{array}{l}3 \\
9\end{array}$ & $\begin{array}{l}9 \\
2 \\
7\end{array}$ & $\begin{array}{r}18 \\
77 \\
2,5\end{array}$ & $\begin{array}{r}90 \\
2 \\
2\end{array}$ & $\begin{array}{c}87 \\
62 \\
0,\end{array}$ & $\begin{array}{l}28 \\
40 \\
91\end{array}$ & $\begin{array}{l}54 \\
61 \\
40\end{array}$ & 2 \\
\hline
\end{tabular}

\begin{tabular}{|c|c|c|c|c|c|c|c|c|}
\hline & 4 & & & & 3 & & 5, & \\
\hline $\begin{array}{l}1 \\
1\end{array}$ & $\begin{array}{l}3 \\
5 \\
, \\
1\end{array}$ & $\begin{array}{l}1 \\
2 \\
2 \\
3\end{array}$ & $\begin{array}{r}18 \\
74 \\
89 \\
8\end{array}$ & $\begin{array}{r}10 \\
62 \\
78 \\
1\end{array}$ & 0 & $\begin{array}{r}56 \\
17 \\
1 \\
3\end{array}$ & $\begin{array}{r}19 \\
62 \\
64 \\
2\end{array}$ & 3 \\
\hline $\begin{array}{l}1 \\
2\end{array}$ & $\begin{array}{l}3 \\
5 \\
4\end{array}$ & $\begin{array}{l}1 \\
3 \\
2 \\
1\end{array}$ & $\begin{array}{r}28 \\
19 \\
61 \\
5\end{array}$ & $\begin{array}{l}17 \\
97 \\
77 \\
8\end{array}$ & $\begin{array}{r}96 \\
04 \\
3\end{array}$ & $\begin{array}{r}19 \\
32 \\
3\end{array}$ & $\begin{array}{r}11 \\
90 \\
40 \\
5\end{array}$ & 3 \\
\hline $\begin{array}{l}1 \\
3\end{array}$ & $\begin{array}{l}3 \\
5 \\
6\end{array}$ & $\begin{array}{l}1 \\
5 \\
8 \\
7\end{array}$ & $\begin{array}{r}63 \\
52 \\
09 \\
3\end{array}$ & $\begin{array}{r}47 \\
61 \\
01 \\
6\end{array}$ & $\begin{array}{r}13 \\
24 \\
96 \\
5\end{array}$ & $\begin{array}{c}16 \\
13 \\
0, \\
8\end{array}$ & $\begin{array}{r}62 \\
56 \\
, 7\end{array}$ & 5 \\
\hline $\begin{array}{l}1 \\
4\end{array}$ & $\begin{array}{l}3 \\
6 \\
9\end{array}$ & $\begin{array}{l}1 \\
5 \\
6 \\
6\end{array}$ & $\begin{array}{l}60 \\
21 \\
77\end{array}$ & $\begin{array}{r}44 \\
75 \\
61 \\
3\end{array}$ & $\begin{array}{r}11 \\
76 \\
50 \\
8\end{array}$ & $\begin{array}{r}11 \\
23 \\
6 \\
5\end{array}$ & $\begin{array}{r}10 \\
01 \\
7\end{array}$ & 5 \\
\hline $\begin{array}{l}1 \\
5\end{array}$ & $\begin{array}{l}3 \\
7 \\
2\end{array}$ & $\begin{array}{l}1 \\
5 \\
4 \\
2\end{array}$ & $\begin{array}{r}56 \\
55 \\
05 \\
3\end{array}$ & $\begin{array}{l}41 \\
60 \\
25\end{array}$ & $\begin{array}{r}10 \\
17 \\
63 \\
1\end{array}$ & $\begin{array}{r}67 \\
24 \\
, 2\end{array}$ & $\begin{array}{r}15 \\
39 \\
3 \\
3\end{array}$ & 4 \\
\hline $\begin{array}{l}1 \\
6\end{array}$ & $\begin{array}{l}3 \\
7 \\
4\end{array}$ & $\begin{array}{l}1 \\
5 \\
0 \\
7\end{array}$ & $\begin{array}{r}51 \\
40 \\
90 \\
5\end{array}$ & $\begin{array}{r}37 \\
21 \\
00 \\
, 2\end{array}$ & $\begin{array}{r}80 \\
65 \\
8 \\
3\end{array}$ & $\begin{array}{l}22 \\
09\end{array}$ & $\begin{array}{r}25 \\
29 \\
8 \\
5\end{array}$ & 4 \\
\hline $\begin{array}{l}1 \\
7\end{array}$ & $\begin{array}{l}3 \\
7 \\
6\end{array}$ & $\begin{array}{l}1 \\
4 \\
6 \\
0\end{array}$ & $\begin{array}{r}44 \\
89 \\
01 \\
7\end{array}$ & $\begin{array}{r}31 \\
69 \\
69 \\
, 4\end{array}$ & $\begin{array}{r}56 \\
17 \\
1, \\
5\end{array}$ & $\begin{array}{r}0 \\
2\end{array}$ & $\begin{array}{r}42 \\
45 \\
3 \\
7\end{array}$ & 4 \\
\hline $\begin{array}{l}1 \\
8\end{array}$ & $\begin{array}{l}3 \\
7 \\
9\end{array}$ & $\begin{array}{l}1 \\
6 \\
8 \\
9\end{array}$ & $\begin{array}{l}80 \\
82 \\
03\end{array}$ & $\begin{array}{r}62 \\
72 \\
64 \\
, 7\end{array}$ & $\begin{array}{r}21 \\
71 \\
58 \\
8\end{array}$ & $\begin{array}{r}52 \\
44 \\
1 \\
5\end{array}$ & $\begin{array}{r}54 \\
7\end{array}$ & 5 \\
\hline $\begin{array}{l}1 \\
9\end{array}$ & $\begin{array}{l}3 \\
8 \\
6\end{array}$ & $\begin{array}{l}1 \\
6 \\
8 \\
4\end{array}$ & $\begin{array}{r}79 \\
92 \\
38 \\
7\end{array}$ & $\begin{array}{r}61 \\
93 \\
70 \\
4\end{array}$ & $\begin{array}{r}21 \\
25 \\
24 \\
, 5\end{array}$ & $\begin{array}{r}50 \\
17 \\
7 \\
2\end{array}$ & $\begin{array}{c}34 \\
2, \\
7\end{array}$ & 5 \\
\hline $\begin{array}{l}2 \\
0\end{array}$ & $\begin{array}{l}3 \\
8 \\
8\end{array}$ & $\begin{array}{l}1 \\
6 \\
7 \\
1\end{array}$ & $\begin{array}{r}77 \\
61 \\
63 \\
9\end{array}$ & $\begin{array}{r}59 \\
90 \\
77 \\
6\end{array}$ & $\begin{array}{r}20 \\
07 \\
07 \\
7\end{array}$ & $\begin{array}{r}44 \\
52 \\
2 \\
4\end{array}$ & $\begin{array}{r}43 \\
, 9\end{array}$ & 5 \\
\hline $\begin{array}{l}2 \\
1\end{array}$ & $\begin{array}{l}1 \\
9 \\
9\end{array}$ & $\begin{array}{l}1 \\
6 \\
6 \\
6\end{array}$ & $\begin{array}{l}76 \\
73 \\
92\end{array}$ & $\begin{array}{r}59 \\
13 \\
78 \\
, 3\end{array}$ & $\begin{array}{r}19 \\
62 \\
64 \\
2\end{array}$ & $\begin{array}{r}42 \\
45 \\
3 \\
5\end{array}$ & 0 & 5 \\
\hline $\begin{array}{l}2 \\
2\end{array}$ & $\begin{array}{l}2 \\
0 \\
\text {, }\end{array}$ & $\begin{array}{l}1 \\
6 \\
7\end{array}$ & $\begin{array}{c}77 \\
44 \\
15\end{array}$ & $\begin{array}{l}59 \\
75 \\
46\end{array}$ & $\begin{array}{l}19 \\
98 \\
24\end{array}$ & $\begin{array}{c}44 \\
11 \\
7,\end{array}$ & $\begin{array}{r}16 \\
, 2\end{array}$ & 5 \\
\hline
\end{tabular}




\begin{tabular}{|r|r|r|r|r|r|r|r|r|}
\hline & 1 & 0 & 8 &, 1 & & 3 & & \\
\hline & 2 & 1 & 78 & 60 & 20 & & & \\
2 & 0 & 6 & 50 & 68 & 52 & 46 & 10 & \\
3 &, & 7 & 11, & 57 & 23 & 67 & 0, & \\
& 4 & 6 & 5 &, 8 &, 7 & 3 & 5 & 5 \\
\hline & 2 & 1 & 78 & 60 & 20 & 45 & & \\
2 & 0 & 6 & 14 & 37 & 34 & 81 & & \\
4 &, & 7 & 71, & 45 & 15 & 2, & 64 & \\
& 6 & 4 & 3 &, 6 &, 5 & 8 &, 7 & 5 \\
\hline & 2 & 2 & 37 & 33 & 22 & 15 & 11 & \\
2 & 1 & 7 & 09 & 08 & 29 & 77 & 02 & \\
5 &, & 1 & 49 & 77 & 06 & 55 & 50 & \\
& 4 & 6 & 0,5 & 7 & 3 & 2 & 2 & 5 \\
\hline
\end{tabular}

Table 4. jarak Ke Cluster

\begin{tabular}{|c|c|c|c|c|c|c|c|c|c|c|}
\hline $\begin{array}{c}\text { DAT } \\
\text { A KE } \\
n\end{array}$ & $\begin{array}{l}\text { CLU } \\
\text { STE } \\
\text { R } 1\end{array}$ & & $\begin{array}{l}C \\
L \\
U \\
S \\
T \\
E \\
R \\
2\end{array}$ & & $\begin{array}{l}\mathrm{C} \\
\mathrm{L} \\
\mathrm{U} \\
\mathrm{S} \\
\mathrm{T} \\
\mathrm{E} \\
\mathrm{R}\end{array}$ & & $\begin{array}{l}\mathrm{C} \\
\mathrm{L} \\
\mathrm{U} \\
\mathrm{S} \\
\mathrm{T} \\
\mathrm{E} \\
\mathrm{R} \\
\end{array}$ & & $\begin{array}{l}C \\
L \\
U \\
S \\
T \\
E \\
R \\
5\end{array}$ & \\
\hline & $X$ & $Y$ & $X$ & $Y$ & $X$ & $Y$ & $X$ & $Y$ & $x$ & $Y$ \\
\hline 1 & $\begin{array}{r}35 \\
7\end{array}$ & 781 & 0 & 0 & 0 & 0 & 0 & 0 & 0 & 0 \\
\hline 2 & $\begin{array}{r}35 \\
9\end{array}$ & 790 & 0 & 0 & 0 & 0 & 0 & 0 & 0 & 0 \\
\hline 3 & $\begin{array}{r}36 \\
2\end{array}$ & 788 & 0 & 0 & 0 & 0 & 0 & 0 & 0 & 0 \\
\hline 4 & $\begin{array}{r}36 \\
4\end{array}$ & 784 & 0 & 0 & 0 & 0 & 0 & 0 & 0 & 0 \\
\hline 5 & 0 & 0 & $\begin{array}{l}3 \\
7 \\
1 \\
8\end{array}$ & $\begin{array}{l}8 \\
9 \\
6\end{array}$ & 0 & 0 & 0 & 0 & 0 & 0 \\
\hline 6 & 0 & 0 & $\begin{array}{l}3 \\
7 \\
1 \\
2\end{array}$ & $\begin{array}{l}8 \\
9 \\
7\end{array}$ & 0 & 0 & 0 & 0 & 0 & 0 \\
\hline 7 & 0 & 0 & $\begin{array}{l} \\
3 \\
8 \\
5 \\
5\end{array}$ & $\begin{array}{l}8 \\
9 \\
7\end{array}$ & 0 & 0 & 0 & $p$ & 0 & 0 \\
\hline 8 & 0 & 0 & $\begin{array}{l}3 \\
9\end{array}$ & $\begin{array}{l}8 \\
9 \\
4 \\
\end{array}$ & 0 & 0 & 0 & 0 & 0 & 0 \\
\hline
\end{tabular}

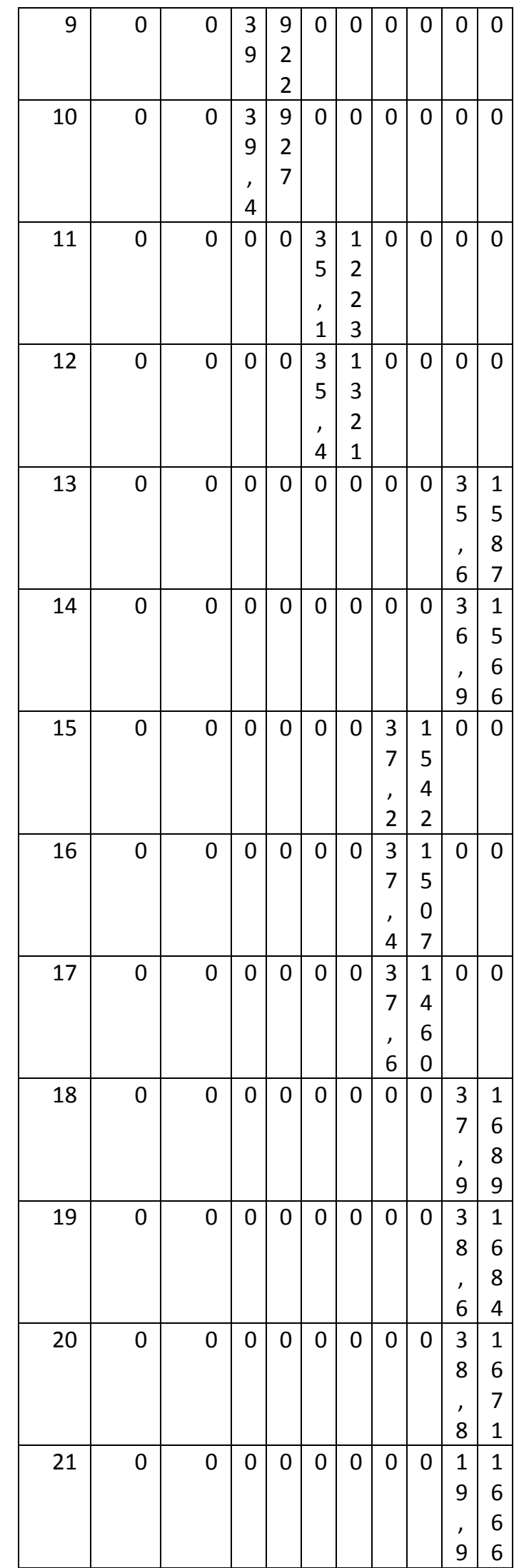




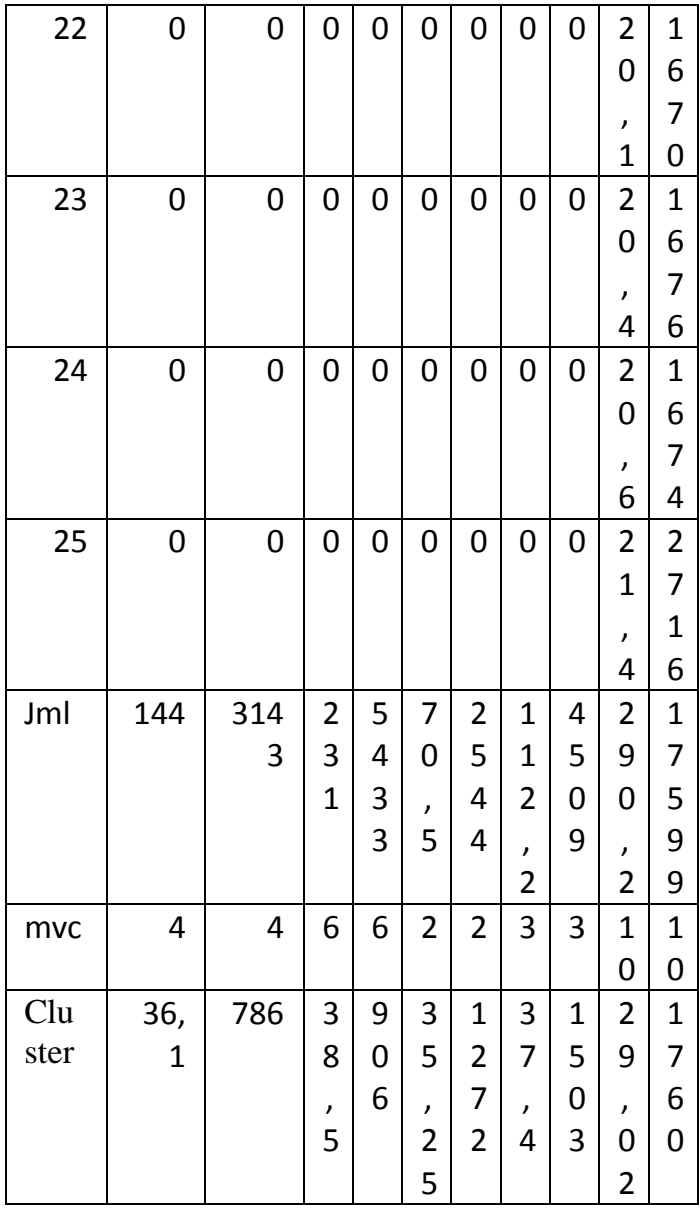

\subsection{A-Priori}

Tabel 4 Kelompok Kinerja

\begin{tabular}{|r|l|}
\hline $\begin{array}{l}\text { ID } \\
\text { Kinerja }\end{array}$ & Kelompok kinerja \\
\hline 1 & $(781,790,788,784)$, \\
\hline 2 & $(896,897,897,894,922,927)$ \\
\hline 3 & $(1223,1321)$ \\
\hline 4 & $(1542,1507,1460)$ \\
\hline 5 & $\begin{array}{l}(1587,1566,1689,1684,1671, \\
1666,1670,1676,1674,2716)\end{array}$ \\
\hline
\end{tabular}

Dari table 4 kita jadikan data tabulasi seperti table 5 dibawah ini :

Tabel 5. Tabulasi data

\begin{tabular}{|c|c|}
\hline transaksi & kelompok transaksi \\
\hline 1 & $(A, B, C, D)$ \\
\hline 2 & $(A, B, C, D, E, F)$, \\
\hline 3 & $(A, B)$ \\
\hline
\end{tabular}

\begin{tabular}{|r|l|l|}
\hline 4 & $(\mathrm{~A}, \mathrm{~B}, \mathrm{C}, \mathrm{)}$ & \\
\hline 5 & $(\mathrm{~A}, \mathrm{~B}, \mathrm{C}, \mathrm{D}, \mathrm{E}, \mathrm{F}, \mathrm{G}, \mathrm{H}, \mathrm{I}, \mathrm{J})$ \\
\hline
\end{tabular}

Dapatkan k-itemset dari support yang memenuhi minimum support, kemudian pilih kitemset sebagai pola frequent tinggi.

Tabel 6. $\mathrm{K}$ item set

\begin{tabular}{|l|c|r|}
\hline ITEM & $\begin{array}{c}\text { BANYAK } \\
\text { TRANSAKSI }\end{array}$ & \multicolumn{2}{|c|}{ Suport } \\
\hline A & 5 & $100 \%$ \\
\hline B & 5 & $100 \%$ \\
\hline C & 4 & $80 \%$ \\
\hline D & 3 & $60 \%$ \\
\hline E & 2 & $40 \%$ \\
\hline F & 2 & $40 \%$ \\
\hline G & 1 & $20 \%$ \\
\hline H & 1 & $20 \%$ \\
\hline I & 1 & $20 \%$ \\
\hline J & 1 & $20 \%$ \\
\hline
\end{tabular}

dari data diatas sehingga didapat :

Tabel 7. Pembentukan Aturan Assosiatif :

\begin{tabular}{|l|r|r|c|}
\hline \multicolumn{1}{|c|}{ Aturan Asositif } & $\begin{array}{c}\text { Suport } \\
\text { (AUB) }\end{array}$ & $\begin{array}{c}\text { Supo } \\
\text { rt } A\end{array}$ & $\begin{array}{c}\text { Confi } \\
\text { denc } \\
\text { e }\end{array}$ \\
\hline$(A, B, C, D)->G$ & $20 \%$ & $80 \%$ & $85 \%$ \\
\hline$(A, B, C, D, E, F)-,>G$ & $20 \%$ & $80 \%$ & $85 \%$ \\
\hline$(A, B)->G$ & $20 \%$ & $80 \%$ & $85 \%$ \\
\hline$(A, B, C)-,>G$ & $20 \%$ & $80 \%$ & $85 \%$ \\
\hline $\begin{array}{l}(A, B, C, D, E, F, G, H, I, J) \\
->G\end{array}$ & $40 \%$ & $80 \%$ & $85 \%$ \\
\hline$(A, B, C, D)->H$ & $20 \%$ & $80 \%$ & $85 \%$ \\
\hline$(A, B, C, D, E, F)-,>H$ & $20 \%$ & $80 \%$ & $85 \%$ \\
\hline$(A, B)->H$ & $20 \%$ & $80 \%$ & $85 \%$ \\
\hline$(A, B, C)-,>H$ & $20 \%$ & $80 \%$ & $85 \%$ \\
\hline $\begin{array}{l}(A, B, C, D, E, F, G, H, I, J) \\
->H\end{array}$ & $40 \%$ & $80 \%$ & $85 \%$ \\
\hline$(A, B, C, D)->I$ & $20 \%$ & $80 \%$ & $85 \%$ \\
\hline$(A, B, C, D, E, F)-,>I$ & $20 \%$ & $80 \%$ & $85 \%$ \\
\hline$(A, B)->I$ & $20 \%$ & $80 \%$ & $85 \%$ \\
\hline$(A, B, C)-,>I$ & $20 \%$ & $80 \%$ & $85 \%$ \\
\hline
\end{tabular}




\begin{tabular}{|l|r|r|r|}
\hline $\begin{array}{l}(\mathrm{A}, \mathrm{B}, \mathrm{C}, \mathrm{D}, \mathrm{E}, \mathrm{F}, \mathrm{G}, \mathrm{H}, \mathrm{I}, \mathrm{J}) \\
->\mathrm{I}\end{array}$ & $40 \%$ & $80 \%$ & $85 \%$ \\
\hline$(\mathrm{A}, \mathrm{B}, \mathrm{C}, \mathrm{D})->\mathrm{J}$ & $20 \%$ & $80 \%$ & $85 \%$ \\
\hline$(\mathrm{A}, \mathrm{B}, \mathrm{C}, \mathrm{D}, \mathrm{E}, \mathrm{F}, \mathrm{)})->\mathrm{J}$ & $20 \%$ & $80 \%$ & $85 \%$ \\
\hline$(\mathrm{A}, \mathrm{B})->\mathrm{J}$ & $20 \%$ & $80 \%$ & $85 \%$ \\
\hline$(\mathrm{A}, \mathrm{B}, \mathrm{C}, \mathrm{)}->\mathrm{J}$ & $20 \%$ & $80 \%$ & $85 \%$ \\
\hline $\begin{array}{l}(\mathrm{A}, \mathrm{B}, \mathrm{C}, \mathrm{D}, \mathrm{E}, \mathrm{F}, \mathrm{G}, \mathrm{H}, \mathrm{I}, \mathrm{J}) \\
->\mathrm{J}\end{array}$ & $40 \%$ & $80 \%$ & $85 \%$ \\
\hline
\end{tabular}

\subsection{Implementasi Rapidminer}

Pertama yang kita tentukan adalah menambahkan data atau kita create data terlebih dahulu sperti Gambar dibawah ini:

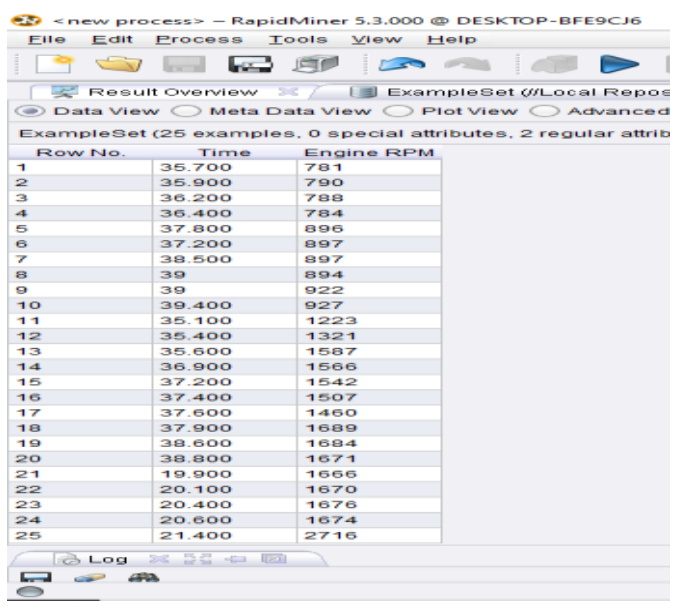

\section{Gambar 3 Data RPM}

Dari data rpm diatas kita tentukan banyak cluster yang akan dibuatdan tentukan proses yang akan dihitung menggunakan metode $\mathrm{K}$ Means, seperti gambar 4 dibawh ini:

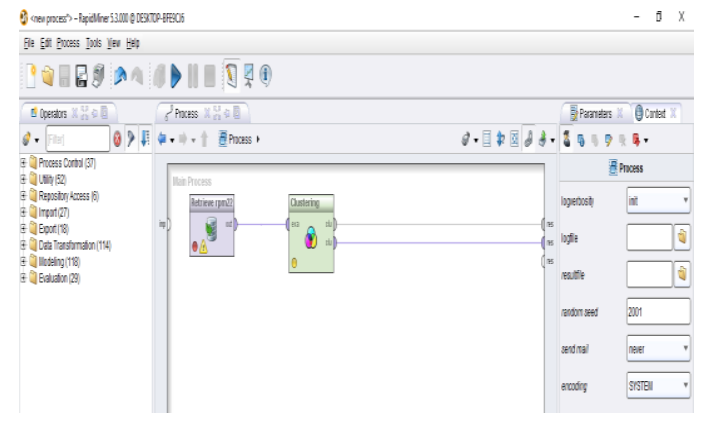

Gambar 3. Diagram Main Proses
Dari Gambar 3 didapat proses clustering seperti pada gambar 5 dan Gambar 6 dibawah ini:

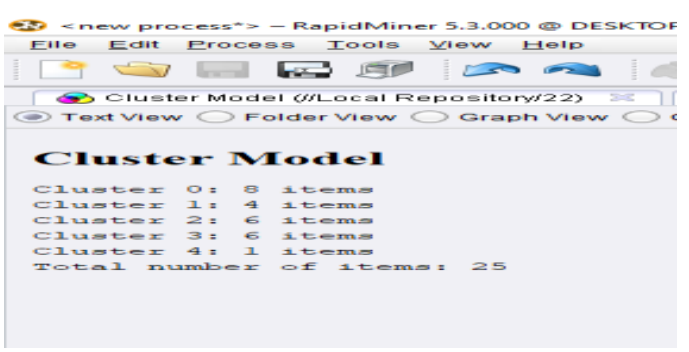

Gambar 5. Culster Model

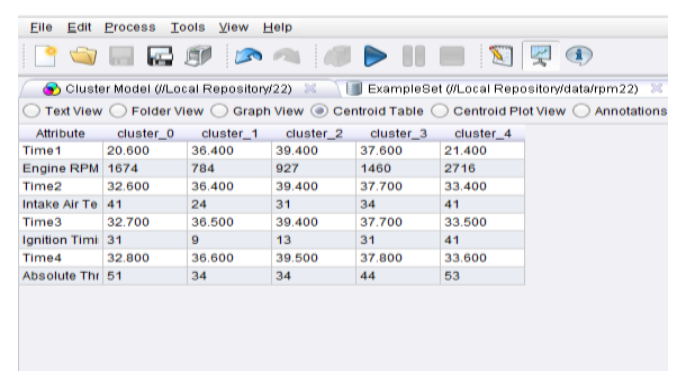

\section{KESIMPULAN}

Dari Hasil penelitian Clustering K-Means didapat $\mathrm{C} 1(781-784), \mathrm{C} 2(896-927), \mathrm{C} 3(1223-$ 1321), C4(1460-1587), dan C5(1689-2716) Engine RPM dan A-Priori Suport AUB ratarata $20 \%$, Suport A rata-rata $80 \%$ dan nilai Confidence Rata-Rata $80 \%$. Berdasarkan Pada remapping variasi 3 derajat pengapian maju menghasilkan Daya mesin dan torsi mesi stabil pada putaran rendah $781 \mathrm{rpm}$ ke putaran tinggi $2176 \mathrm{rpm}$ dengan remapping derajat pengapian maju $4^{\circ}$ deggre sesuai dengan kondisi mesin pada saat pengujian.

\section{UCAPAN TERIMAKASIH}

Terimakasih kepada Kementerian Riset Dan Teknologi / Badan Riset Dan Inovasi Nasional Deputi Bidang Penguatan Riset Dan Pengembangan. STMIK Dian CIpat cendikia Kotabumi.

\section{DAFTAR PUSTAKA}

[1] Saleh, Alfa. 2015. Implementasi Metode Klasifikasi Naïve Bayes Dalam Memprediksi Besarnya Penggunaan Listrik Rumah Tangga. Citec Journal. Vol. 2, No. 3, Mei 2015 - Juli 2015, ISSN: 2354-5771. 207-217. 
[2] Wanto, Ajar Dkk.2020.Data Mining: Algoritma dan Implementasi.Yayasan Kita Menulis .Medan.

[3] Kaur, Noor K., Kaur, Usvir., \& Singh, Dr.Dheerendra., 2014. K-Medoids Clustering Algorithm - A Review. [pdf] International Journal of Computer Application and Technology (IJCAT). ISSN. 2349-1841 Vol. 1, Issue 1. April 2014.

[4] Bhat, Gh. Mohd., M. A. Mukhdoomi, B. A. Shah, Mohd S. Ittoo. 2014. Dermatoglyphics: in health and disease - a review. International Journal of Research in Medical Sciences. 2(1):31-37.

[5]https://www.oto.com/berita motor/mengenalfungsi-ecu-pada-motor, diakses tanggal 15 Oktober 2020. 